\title{
Renaissance Dress, Cultures of Making, and the Period Eye
}

Ulinka Rublack

University of Cambridge, United Kingdom

This article argues that fashion was at the forefront of Renaissance visual styles. This makes it as important as paintings for understanding the Renaissance as an aesthetic movement. An understanding of fashion follows from a knowledge of how things were made and what visual skills were involved in the making processes. I propose that we see tailoring as akin to a process of polychrome sculpting and investigate the significance of color making. The article explores the political and emotional meanings of color in the early sixteenth century and demonstrates how remaking can be part of a heuristic process for academics. Building on Michael Baxandall, the article concludes that dress needs to become firmly embedded in our conception of the period eye.

In the visual properties of a work of art one can identify cultural visual skills. —Michael Baxandall

I

This article asks how we can accommodate the extraordinary importance of clothes in creating culture and a visual public in Renaissance symbolic practices. Both everyday dress and its display are humanly crafted complexes of form-and this now serves as a definition of art. Many people in this period composed a careful three-dimensional image of themselves through dress, and at far greater expense than any pictorial image. No printed guide for tailoring existed until Juan de Alcega published his Tailor's Pattern Book in 1589 in Spain. It, as much as the tailoring manuscripts which preceded or followed it, lacked detailed instructions and followed basic geometrical shapes. Every garment 
created from a pattern in the book therefore differed. Making resulted from a creative process of embodied cognition, as the process of tailoring turned on an intuitive sense of bodily proportions and how dress shaped them. This process was deeply sculptural and interlinked cognitive and somatic awareness of how clothes and accessories would come alive on the body of a wearer through their properties, such as weight and color, and through movement. ${ }^{1}$

It therefore comes as little surprise when Benvenuto Cellini explains that after making the "soul" (the core form for casting in bronze) of his Perseus, he "clothed [this] with those earths [he] had prepared" (io vestivo il mio Perseo di quelle terre che io avevo acconce). ${ }^{2}$ This sense of tailoring as akin to sculpting and sculpting as resonant with dressing was embedded in a culture whose entire economy and everyday life were tightly interlinked with an ever increasing spectrum of textiles. In regard to Venetian painters and their patrons, Paul Hills concludes, "More than anything, it was through the dress they wore and touchedtheir camouflage and sign of distinction-that Venetians, patrons and painters alike, became cognitively attuned to color texture, to colorito." ${ }^{3}$ Fabrics inspired the multitextured and polychrome effect of sculptural surfaces, which Michael Baxandall describes as "resonant with the marvellous gamut of Renaissance textile surface—satin, damask, camlet, velvet, silk, taffeta, tabby, brocade."

Renaissance dress in turn can be thought of as a form of polychrome sculpting, thick in sensorial and affective experience that related as much to the materials that were used as to the shapes that were achieved. Men were laced into tightfitting hose (leg garment) and doublets (upper garment) for a slimmer, more streamlined silhouette. The sculpted codpiece, a mock erect phallus, came in different shapes and sizes and was frequently unfastened during the day. Many forms of work as well as sports and military activities were carried out in voluminous pleated shirtsleeves. Women wore farthingales under their skirts as a kind of scaffolding to create a wide bell shape and greatly extend their volume in space. ${ }^{5}$ John Donne's elegy "To His Mistress Going to Bed" turns the prolonged undressing of a woman, layer after layer, into an erotic act culminating with his "roving hands" exploring the "America" or "new-found-land" of her naked body. ${ }^{6}$ The body, bodily memory, and aspects of subjectivity thus were known and experienced in relation to matters of dress. ${ }^{7}$

Garments from this period need to be seen as astonishing achievements in skill, imagination, and dexterity in a creative response to the particular properties of a wide range of materials. From 1540 onward, for instance, fine slashed shoes in paper-thin leather were made in ways which now can be achieved only through laser-cutting techniques. ${ }^{8}$ These shoes were expensive, specialized items. Large knitted woolen headwear, by contrast, became one of the most affordable fashion items for men and women. Their felting enabled interesting shapes if shrinkage was carefully calculated. Urban magistrates could proactively stimulate trade in such goods, as when Nuremberg's councillors decided to "write to the Lords in Aachen" in September 1520 to find out "in Cologne whether they can get someone to start the trade with silk and cap-making and make them

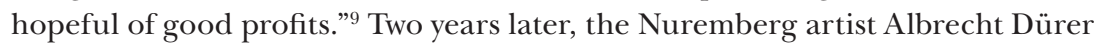
used a monumental woodcut to depict his friend Ulrich Varnbüler as lifelike as 


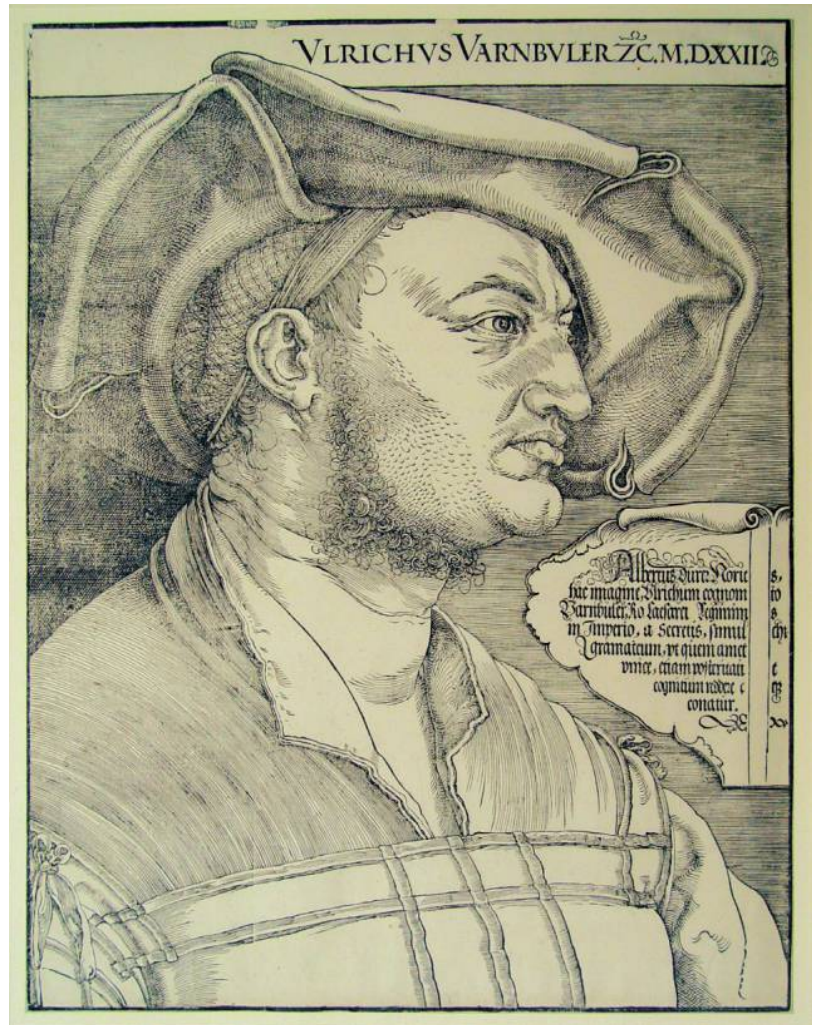

possible with one of these attention-grabbing, tangibly three-dimensional caps. ${ }^{10}$ Dürer once designed his own shoes, and he keenly shopped for dress items. Shapes, textures, and beautiful dyes fascinated him the most. In March 1521, Dürer spent the substantial sum of over three florins on five silk girdles in Antwerp, as well as more than five florins on precious silk cloth. He bought trims, several pairs of gloves for women, a large beret for the aging humanist Willibald Pirckheimer, a partlet in deep-red dye for another male friend, two purses for women, and a decorated scarlet beret for a three-year-old boy. ${ }^{11}$ Dress and dress accessories, as much as or even more so than painting, were at the forefront of visual styles.

This passion for dress was part of a world in which subtle crafting was increasingly prized, along with the intrinsic value of traditional luxury materials, generating excitement and awe. Descriptions of royal, imperial, or papal appearances typically specified the magnificence of key figures through the fantastic wealth of their jewelry, silk garments, or fabrics made from gold or silver thread. This narrative convention identified traditional treasure and continued a medieval ideal of luminescent splendor, which was as central to sacred art as it was to embodiments of secular power. Gold mosaics, glass windows, bejeweled reliquaries, and silk vestments were all forms of ornamentation that reflected light, and light was associated with spiritual illumination. Light could also symbolize God, as it animated and continuously transformed surfaces. ${ }^{12}$ Courtly dress in 
just the same way tried to maximize the light-reflecting properties of its fabrics. Writers emphatically dwelt on these gleaming appearances from the twelfth century onward, going so far as to say that they were brighter than daylight and even shone at night. ${ }^{13}$ By the fifteenth century, the body of a Sforza prince would still be described in these terms - as polished, splendid, or lustrous and thus comparable to a "living sun." This impression was the effect of unparalleled conspicuous consumption at the time, so much so that Galeazzo Maria Sforza owned sleeves which had over three thousand pearls and forty rubies sewn onto them. Even spurs and shoes could be adorned with gold and other light-reflecting substances. ${ }^{14}$

The new emphasis or focus on craft during the Renaissance implied an even higher valuation of how materials were transformed. Peter Martyr in 1521 thus praised the artistry of the people of Yucatán and Mexico by writing to his humanist friends, "I wonder not at all the gold and gemstones, but at the skill and workmanship which far exceeds the value of the materials. I am amazed." 15 More radical followers of this bourgeois aesthetics insisted that the intrinsic value of materials was irrelevant, or even a distraction, in judging art. Erasmus lectured the young John More in 1523 that "a great artist is always himself, whether he is modelling a colossal statue or a six-inch statuette [or] whether he is engraving bronze and ordinary stone or precious stones and gold." The humanist continued his lesson: an object of "small value or small size" allowed one to admire the maker's skill even more. ${ }^{16}$

These contestations over the value of matter inspired a new crafts luxury which attracted a bourgeois clientele and gave specialized artisans confidence as patron and artisan worked together on commissions. In relation to fabrics it is important to point out that new evaluations of craft achievement often coexisted with the traditional esteem for bright colors and luminosity. Michel Pastoureau's notions of a "triumph of black" supported by Protestant "chromoclasm" do not adequately describe sixteenth-century dress aesthetics. ${ }^{17}$ The Nuremberg patrician Magdalena Behaim, for instance, reported on the bright-pink clothes worn by some men at a Lutheran wedding in 1591: "Paulus Scheuerl, Benedict and Hans Imhoff wore three beautiful completely new saflor-colored silk-satin breeches and doublets with golden trims; at the afterwedding event Anthony Tucher wore the same kind of breeches and doublet." Then follows an astonishing sentence: "And so the old world has renewed."18 Colors set off entire affective atmospheres.

The Behaim-Paumgartners of Nuremberg traded in northern Italian fabrics and hence were at the center of a highly sensitized world of color appreciation in advanced cities. New dye tones must have created one of the foremost visual experiences in this period. The spectrum of dyes considerably widened throughout the sixteenth century, building on Asian and Mediterranean knowledge, new dye-recipe collections, and the greater diversity, through New World trade, of available plants whose rinds, roots, berries, leaves, and flowers formed the basis of vigorous experiments to create new medicines, pigments, and dyes. ${ }^{19}$ Colonial plants were increasingly acclimatized in botanical gardens and tested for their properties..$^{20}$ The creative use of organic vegetable, animal, and mineral matter 
to make colors and fasten them on fabrics deeply fascinated contemporaries, not least because such work promised to mimetically achieve the vibrant natural colors in the world around them, which, decade by decade, they knew much more of. They thereby participated in an enlivening process of making that replicated God's own art. ${ }^{21}$

The importance given to such experiments registers most impressively in the confidence with which the Venetian Gioanventura Rosetti introduced, in 1548, the first specialized and astonishingly comprehensive printed manual of dyeing and leather tanning. The Plictho, as it was called, was intended to benefit "moderns" with hundreds of recipes. ${ }^{22}$ Rosetti championed the dissemination of knowledge for the benefit of everyone against a culture of hidden secrets for the benefit of a few, and he was clearly inspired by evangelical ideas which at the time circulated in Venice:

You must know that this is a work of Charity that I bequeath for the public benefit, and which has been imprisoned for a great number of years in the tyrannical hands of those who kept it hidden and thus subject to Evangelical indignation, wherein it is written that nothing shall remain hidden that has once been revealed, nor concealed so that it is not evident. Wherein sweetest Readers I cajole you not to be subject to apostolic censure by dulling the virtue that the glorious GOD has wanted that men be endowed with, and for their comfort you can prosper and use it for the benefit of everyone. ${ }^{23}$

Rosetti worked in the Venetian arsenal-its shipbuilding complex-and yet he claimed to have collected and even paid for recipes from as far away as Syria during a period of sixteen years, so that Venetian "coffee houses and workshops" would "expand with the growth of masters who will wish to exercise these arts." His book went through two further editions within just twenty years, followed by another two editions by 1672, doubtless encouraging comparative testing and categorizing as well as commerce.

The Plictho was a leap in the dissemination of knowledge. A small number of short recipes for dyes had been incorporated into both a Dutch and a German publication by 1532, and the latter limited itself to instructions on how to dye linen and yarn in brown, blue, and red. ${ }^{25}$ Rosetti was incomparably more comprehensive because he distinguished not only among a wide range of colors but among different shades ("rusty red," "green over azure," "half scarlet," "faded blue"); supplied a great variety of recipes, such as eight recipes in sequence for a "very beautiful black"; included many types of matter to be dyed, ranging from fustian to silk and from leather to feathers; and referenced particular traditions, such as Venetian expertise in dyeing scarlet or instructions on how "to dye in crimson color according to Master Raimondo of Florence." Finally, Rosetti's recipes were unusually detailed according to the standards of the time. This underscored his claim that quality dyeing was an "intricate" and indeed "ingenious art." It was, he argued, "fit for acute intellects and requires as much diligence as any other [art] that can be mentioned." 26 
His recipe for dyeing berets in scarlet gives us a sense of the type of sophistication Dürer might have delighted in when he bought a beret in Antwerp, and of the advanced chemistry through the use of minerals involved in some recipes:

To dye berets in scarlet

First you take 4 ounces roche alum for each pound of berets, and make it boil two hours. Then you will take the berets and wash them in running water. Wash them well and heat them well upon a table. Then you take fresh water and put it into the fire and make it be sizzling hot. Then you take a small cauldron of strong water with bran and fresh water. You will take the berets and let them be fortified in said water, and then take the grain and put it in and make it blossom. Then throw in the berets and turn them over often. Then cool them so that they be finished to your liking. Then you will take a bucket of fresh water in a cauldron. Make it sizzle and then you take the bran, that is two small handfuls, and then two other handfuls of dry bran and throw them into the said water. Then you take one quarto of sal niter, and one quarto of arsenic for each pound of berets, that is, one quarter of an ounce, and dissolve in a little vessel with the sizzling water. Then you take half a bucket of water and make it sizzle, and then take 4 ounces of burnt alum of lees, and put it into the said water. As it raises the boil pull it away. Take two dippers of said water and put it in the first. As the said water begins to boil, take the said arsenic and sal niter and throw it into the said water and mix well. Then take your berets, and turn them over and over inside with a stick and often make them cool. ${ }^{27}$

German manuscripts and books in which we find dye recipes are called "little books of art" (Kunstbüchlein) or "little books of trying things out" (Probierbüchlein). They point to widely distributed practices of making which were available to craft specialists as well as laypersons during this period and addressed renewed concerns about how to foster well-being and how to dress. These concerns could be experienced as connected, as when particular colors were worn to enhance well-being or protect the wearer from bad humors. The Augsburg merchant Hans Fugger in 1569 thus went to great effort to obtain a particular "subtle" tone "burning with color" from a widow near Landshut to decorate his dance hall and enliven people in civilized ways. ${ }^{28}$ Around the same time, a young Fugger employee wore black to protect himself from emotional turmoil in relation to his family. ${ }^{29}$ Colors were seen to affect body and soul, so that their re-creation in specific tones accordingly enlarged the range of emotional possibilities and, by extension, the way to exist in the world. Colors were, as Spike Bucklow argues, not necessarily ephemeral, fashionable commodities to further commerce but could be valued for intrinsic properties. ${ }^{30}$

All this implies that we need to reorient our research agenda to include clothing and colors as signal media of symbolic communication and as integral to emotional experiences and innovative crafting in the sixteenth century, to fully understand the visual appreciation and discernment skills of ordinary people during the Renaissance. Yet material historians grapple with the dilemma 
that most early modern dress is lost, has changed or lost color over time, or, if preserved and displayed in museums, is presented statically, with very low and uniform lighting. I argue that historical reconstruction can aid an endeavor to understand the complexity and sensuous vibrancy of early modern dress. In the next section, I will use the reconstruction of a particular garment to explore how Matthäus Schwarz, head accountant of the Fugger merchant firm and one of this period's foremost creators of fashion, used dress as a politicized visual act. Schwarz's use of complex dress items to generate visual interest underlines that aesthetics in this period was not limited to the realm of the genius artist but was informed by that far more inclusive culture created by a larger group of urban citizens, bound together in networks of material knowledge, who made decisions about how to express themselves through their attire, gestures, and comportment, and who as customers drove craft innovation. Schwarz commissioned the garment in question to make an impression at the Augsburg Imperial Diet in 1530. This was one of Germany's most precarious political summits during a period of religious divides.

\section{II}

Matthäus Schwarz was born in the Free Imperial City of Augsburg, in southern Germany, in 1497. In 1520, at age twenty-three, he began compiling 137 watercolor images of himself dressed retrospectively from when he was a baby to when he considered himself an old man. He called this project his "Little Book of Clothes," and it presents an unparalleled historical record of early modern fashion. ${ }^{31}$ Schwarz was a local wine-merchant's son, and at age sixteen he traveled to Venice to learn accounting. He lived in the Foundation of the Germans at the Rialto Bridge, in which the Fuggers rented lodgings for their agents, and he reported that he learned bookkeeping rather leisurely, on a gondola in the lagoon. Just like Dürer, who had used his Venetian trips to buy jewels, dress, and feathers, so Matthäus Schwarz would have been fascinated by the global "worldly goods" and the cultures of making which enriched this Renaissance city. Venice excelled in the production of scarlet-red dyes, and it was the first European city with shopkeepers who specialized in selling coloring materials-aptly named vendicolori. These shops drew on imports from the mining and metal-processing areas of the German lands, especially azurite and green copper, and made possible tremendous variety in coloring agents; the color merchants in Venice provided a "nexus for communication among all types of artisans who used colors, fostering technological innovation." ${ }^{32}$ It is easy to imagine that discerning customers interested in dress would have been fascinated by their wares.

After his return to Augsburg in 1516, Schwarz's life became linked to his service to the Fugger merchants. This family had risen from the modest fortunes of an immigrant weaver in Augsburg to unprecedented wealth and power through their loyalty to the Habsburgs and to Catholicism. Jacob Fugger the Rich is the only other adult person who features in the entire "Little Book of Clothes"-in 1516, as he dictates to Matthäus Schwarz, who has just been entrusted with the accounting for the firm, at age nineteen. From then on, Schwarz's aesthetic judgment, commercial acumen, and diplomatic skills would become trained in the 
Fig. 2

Matthäus Schwarz with Narziss Renner

(illuminist), "Little Book

of Clothes." Image

67, 1524. Herzog

Anton Ulrich Museum, Brunswick, Germany.

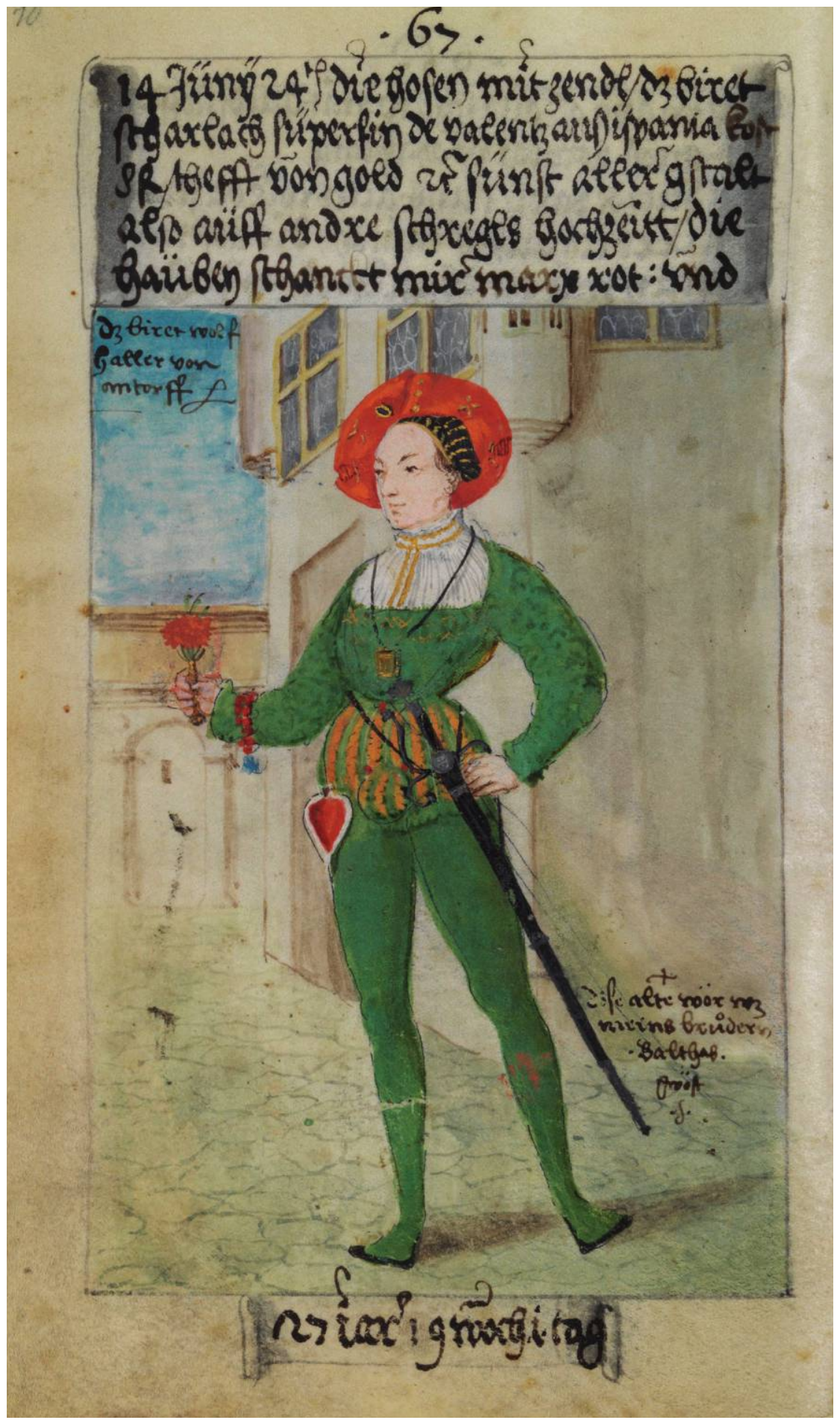


process of procuring what he called "subtle merchandise" (subtille kaufmannschaft) for the Fugger firm, ranging from silks, damasks, velvets, "gold and silver cloth" from Venice, and dyestuff to precious stones, spices, and rhubarb for medicinal purposes. ${ }^{33}$ The Fuggers' involvement in mining was at the heart of their success, and Schwarz himself not only sat in the company's writing chamber but also rode on business to the Tyrolian mining town of Schwaz, and thus would have been intimately familiar with particular fine pigments processed there. ${ }^{34}$

Most of the images in the "Little Book of Clothes" date from a period of twenty years, when Schwarz was single and collaborated with Narziss Renner, a slightly younger illuminist who painted the watercolors of Schwarz. Schwarz invested time and emotional energy in his promotion, social activities, sports, and flirtation. Many of his outfits show how male dress not only served as a tool of powerdressing, to secure professional achievement and privilege, but also expressed emotional sensibilities. ${ }^{35}$ One of the watercolors, for instance, shows him at age twenty-seven in a tight-fitting green outfit, with a heart-shaped bag in red, a red coral bracelet, and a bright scarlet bonnet. ${ }^{36}$ Green was a difficult dye to achieve and make fast. The entire outfit constituted Matthäus Schwarz as a young aesthete in search of love as he was about to reach full manly maturity. ${ }^{37}$

Yet, despite his sartorial efforts and widening connections it remained impossible for Matthäus Schwarz to marry a local patrician. One reason for this must have been the dishonor brought on the family by his grandfather, who had been elected as first mayor of Augsburg by the craft guilds but was later executed for corruption. Matthäus's success was such, however, that in mid-life he was granted his own coatof-arms by the Habsburgs and entrusted with managing the event which eventually must have helped restore the family's good name: the Imperial Diet of Augsburg in 1530. Germany at this time was part of the Holy Roman Empire; the emperor was chosen by seven prince electors from the German lands. Diets were summits which allowed princes and other political leaders to come together and discuss their concerns. Recent research stresses that rituals during these events "bound all of the participants to the reciprocal relations that were symbolically staged before the entire public" and could bring about what they represented. Ritual, comportment, and other forms of symbolic communication hence constituted an important aspect of politics. As the Renaissance was challenged by the Reformation, its grammar and vocabulary became deeply contested. ${ }^{38}$ Schwarz's dress at the Diet can thus be analyzed as a visual act within a chromatic politics during the age of the Reformation, for which symbolic communication was key.

\section{III}

The outlines of the Diet are quickly sketched. In February 1530, the Habsburg ruler Charles V was crowned Holy Roman Emperor by Pope Clement VII in Bologna. As the snow on the Alps began to melt later that spring, Charles headed to Germany, leaving some of his troops behind to destroy the Florentine republic and re-install the Medici. Charles had been in Germany only once, at the very beginning of his rule as emperor, at the momentous Diet of Worms in 1521. He spoke French and some Latin but no German. 
Since 1521, religious heresy had spread uncontrollably. Martin Luther, the German reformer, remained under an imperial ban but built up his bastion in Saxon Wittenberg. For Charles and his advisors Germany was a land in which too many had passionately fallen into unbelieving "error." The "only means against it" would be for him to be present himself. It was clear to Charles's mind that he remained "their sovereign, rightful and natural overlord and protector of all Christianity." He asserted his divinely bestowed superior authority as sacred head of the empire together with the pope ${ }^{39}$ The most important measure was to ensure control of the public space.

Augsburg was a volatile city, and at the time of the Diet in 1530, it turned into the pop-up center of German political and courtly life. Foreign traders arrived, as the usual prohibitions against them were discarded, and they occupied designated stalls in the market. Sumptuary laws were lifted. An Imperial Diet was a commercial event, which in 1566 added an estimated ten to fifteen thousand people to the usual number of about thirty thousand citizens.$^{40}$ Emperor Maximilian II in 1572 issued an ordinance specifying which artisans were allowed to follow his travels and be exempt from local customs and taxes. The group included six makers of trims and feathers as well as seventeen tailors. Tradesmen offered luxury wares such as purses, gloves, stockings, and mirrors. ${ }^{41}$

In 1530, excitement about shopping for luxuries mixed with fears about militancy, so much so that the town magistrate hired four hundred mercenaries and then had to accept one thousand men under Charles's command. ${ }^{42}$ Chronicles report a widespread mood among the common folk that nobody "wanted the emperor." "43 "Augsburg belongs to the emperor" some were told in return by his violent guards, who broke down any door which was not opened to them. ${ }^{44}$ The magistrate ordered the city gates and public squares secured with chains and reinforced by guards day and night in the following months. ${ }^{45}$

Charles arrived in June, almost two months later than expected. German princes had spent weeks entertaining themselves in the city with increasing impatience. There was Protestant preaching, accompanied by several religious provocations and disturbances. Excrement was thrown at coats-of-arms which marked the living quarters of high-ranking guests. The Protestants had greeted reports of Charles's coronation in Bologna with hostility about its pompousness, which seemed as much a shallow show of power as Catholic ceremonies were silly concoctions, resembling "child's play" or a "puppet-show," to create a whole false world which had nothing to do with real faith. Lazarus Spengler, Nuremberg's Lutheran city scribe, noted, "Our people at the imperial court inform us that his imperial majesty ... has been crowned by the pope ... with almost inappropriate pomp (unmessiger kostlikait)," while the Protestant Prince Philip of Hesse received news that "everything was ridiculous with the crowning ceremonies between the emperor and pope. ${ }^{" 36}$ Luther opened his printed address to the clergy who had gathered in Augsburg for the Imperial Diet by pointing out that even if he were allowed to be present in Augsburg, he should be of no use, as he "really did not care about all the splendor and dealings." ${ }^{, 77}$ 


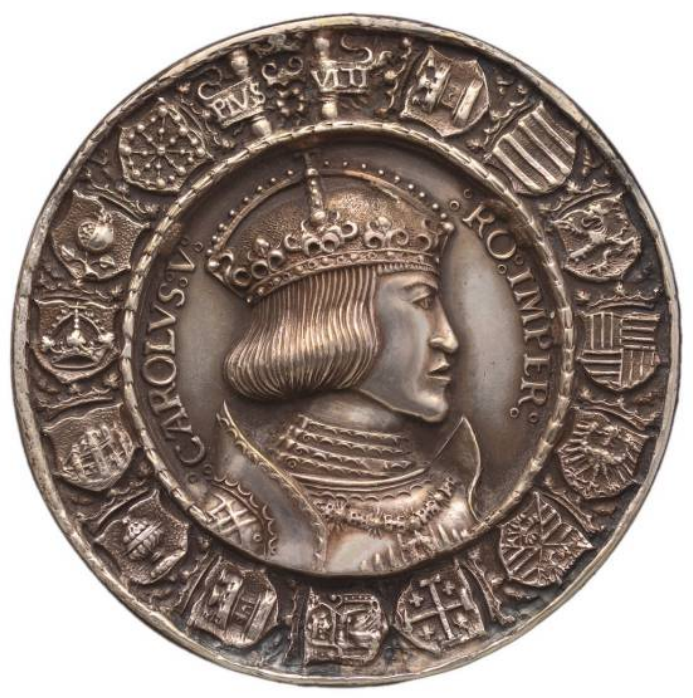

Fig. 3

Albrecht Dürer (designer) and Hans Krafft the

Elder (maker), Charles V silver medal, 1521. $7.1 \mathrm{~cm}$. National Gallery, Washington, DC.

\section{IV}

Charles V entered Augsburg on a particularly hot day in an unusually warm year. According to the order of entry Charles had first issued, he as emperor would ride under the new, splendid cloth-of-gold canopy embroidered with the imperial eagle. Ferdinand, Charles's brother, would be on his right, and Campeggio, the papal legate, on his left. The canopy was a sacred textile, and through its sensuous appeal and extraordinary luminosity, it would symbolically communicate majesty and a divine order. Such canopies were always used in the most significant church feasts-for instance, to shield the host in Corpus Christi processions. The prince-electors made clear that this order was unacceptable. In the end, the electors of Mainz and Cologne rode in advance of Charles, who rode beneath the cloth of gold. Ferdinand and the papal legate were at either side but not beneath the canopy-Campeggio uncomfortably on a donkey to demonstrate humility. Color, ceremony, and performance thus mattered deeply as part of "real politics." The empire itself was staked out by symbolic means. ${ }^{48}$

The pressing question remained, who could be convinced to greet the entry, according to custom? Augsburg's intensely nervous and internally divided magistracy sent out men to knock at every house and ask citizens to take part in the ritual procession, which led out of the city to the bridge over the Lech River. Clemens Sender, a Catholic chronicler, noted that about a thousand artisans, "mercenary-like folk cobbled together from all guilds," attended, alongside the clan of the Fugger merchant company with thirty-two "splendid" men as well as the town's most honorable families. Sender continued: "As long as Augsburg has existed, there has never been so many foreign folk from so many nations." Among the two hundred foreign princes and potentates were Africans and Arabs and high-ranking noblemen from Hungary to Alsace "in all sorts of dress"- a visual and aural splendor with trumpets and drums which almost "echoed across the globe." ${ }^{49}$ 
The emperor wished to restore Catholic predominance, and immediately after his arrival, the feast of Corpus Christi was celebrated on the 16th of June at his behest, with all due solemnity. However, the Protestant princes did not attend, nor did the guilds, as they were meant to. A mere one hundred male and female citizens were present. ${ }^{50}$ In this politics of presence and spectacle, nonattendance was the most pointed act of resistance against the emperor's symbolic directorship, which always presumed a unity of secular and spiritual governance.

Protestant services were stopped, and Protestant preachers were forced to leave town. Every citizen was forced to attend the oath of loyalty on the 27th of June. A censorship commission prevented any printing of evangelical matter. Street violence remained routine, despite draconian measures by the Spanish contingent that had arrived with Charles. During the first ten weeks of the Diet a total of 164 people were executed for different "crimes," among them 40 local men and women. The magistracy was paralyzed by fear of the reaction both of the emperor and of the common people. ${ }^{51}$

At the Diet itself, Charles attempted to avoid any open aggression with Protestants-the directive was to calmly reject their demands and negotiate. A chair covered in cloth of gold ritually constituted his space of distinction. Gold, jewels, and pearls distinguished his ceremonial vestments as he granted fiefs, with their privileges, to the electors. The Catholic chronicler Clemens Sender followed exactly the aesthetics of reading for treasure and the very costliness of precious materials when he reported that all this was "done in the most precious manner, as has never been witnessed before; one has estimated that the crown and imperial dress is worth more than three times a thousand florins. ${ }^{{ }^{2} 2}$

The most important objective was to secure Ferdinand's election as king of the German lands. To prepare the way for Ferdinand's ascending the throne, Charles first installed his brother as archduke of Austria in a ceremony on the 5 th of September. This crucially gave Ferdinand the right to alter the status of anyone in the German lands, to ennoble citizens such as Matthäus Schwarz and grant coats-of-arms. As before the election of the emperor in 1519, the Fuggers provided the money which the Habsburgs passed on to German prince-electors in sealed linen sacks filled with hard coin. Now the Habsburgs needed the Fuggers' support for Ferdinand's election as king. ${ }^{53}$

The ceremony in September took place in nearby Wellenburg, which was in the possession of the powerful cardinal Matthäus Lang. It was of course staged to be exceptionally splendid and showy—not least through the appearance of the court giant and dwarf together on a camel. It used the wider entourage with great effect to demonstrate the international reach of Charles's power. Ferdinand was dressed in a scarlet-red archducal mantle trimmed with ermine and a matching bonnet. ${ }^{54}$ Here was the glory of a dynamic world empire, which hunts, tournaments, and other entertainments had likewise demonstrated during the past months.

The Protestant princes left Augsburg before the Diet's decisions were read out in November so as to avoid having to accept a "rotten peace" and consent to 
disputed articles. Augsburg itself refused to accept the Diet's decisions and chose to compensate the emperor with payments. ${ }^{55}$ Even as Charles departedattired in the same dress as he had arrived in-he ordered a man to be executed in front of the town hall for "rumouring."

\section{V}

"Presence meant acceptance." We can therefore sum up the logic of these politics with Barbara Stollberg-Rilinger, for "whoever took part in a public, symbolicritual act demonstrated his accord and showed that he would keep to the expectations connected to [the event] in future. ${ }^{, 57}$ Bodily appearance-both in terms of physical presence as well as manner of dress-mattered, as did carefully calculated ritual, in an age of increasing complexity and decreasing consent. ${ }^{58}$ Even the presence of the ordinary citizenry mattered, in particular if they visually expressed their consent. This is exactly what Matthäus Schwarz chose to do and how we must understand the politics of his ensemble. Schwarz's outfit underlined the closeness of yellow to the brilliance of gold and the sun, which would be particularly captured through the reflection of light on the Italian patterned damask he used for the doublet, endorsing a mood of joyous splendor and asserting his alliance to Ferdinand and the Catholic cause. He explicitly recorded that he had his clothes made to "please Ferdinand."

The choice of colors worn at summits up to the 1540s was not usually influenced by heraldry. Nor was it determined by sumptuary legislation, which did not regulate dyes. Rather, color was a political sign which showed that one possessed the same courage and will. Wearing the same color signaled unity, belonging, and power, and in order to create an impression, princes coordinated in advance which color they would appear in and handed out fabrics. ${ }^{59}$

Color displays therefore suffused political events. It was deemed important to avoid "childish or carnival colors," whereas one or two colors appeared valiant and signaled "constancy." Nearly 5 percent of expenses at the Saxon court were on dress. ${ }^{60}$ In March 1526, John the Steady of Saxony thus wrote to Duke Heinrich of Mecklenburg to let him know that he and Philipp of Hesse had agreed on a color to wear at an imperial diet and to request that Heinrich follow them. He soon sent a pattern of the outfit in brown as a sample, as well as the customary Lutheran device "God's word in eternity," which all three would have embroidered on the sleeves of their entourage. Yet the Ravensburg trade company in 1507 had been unable to sell brown velvet from Milan, as it was "too dark and has no gay [fröhliche] color." ${ }^{61}$ To achieve a more defiant, joyful look the Ernestine Saxon princely advisors told the court and nobility before the 1530 Imperial Diet to dress in "liver-color," which was light red or red brown. Philipp of Hesse once more agreed to adopt this color as well as the device. ${ }^{62}$

A particular problem was not to appear in the color sported by key Catholic parties, especially as it was the bulky Lutheran John of Saxony's duty to carry the imperial sword in front of the emperor during their formal entrance. At imperial gatherings, black was associated with the Spanish, and in 1530, the 
Fig. 4

Matthäus Schwarz with Narziss Renner (illuminist), "Little Book

of Clothes." Image 102/3, 1530. Herzog Anton Ulrich Museum, Brunswick, Germany.

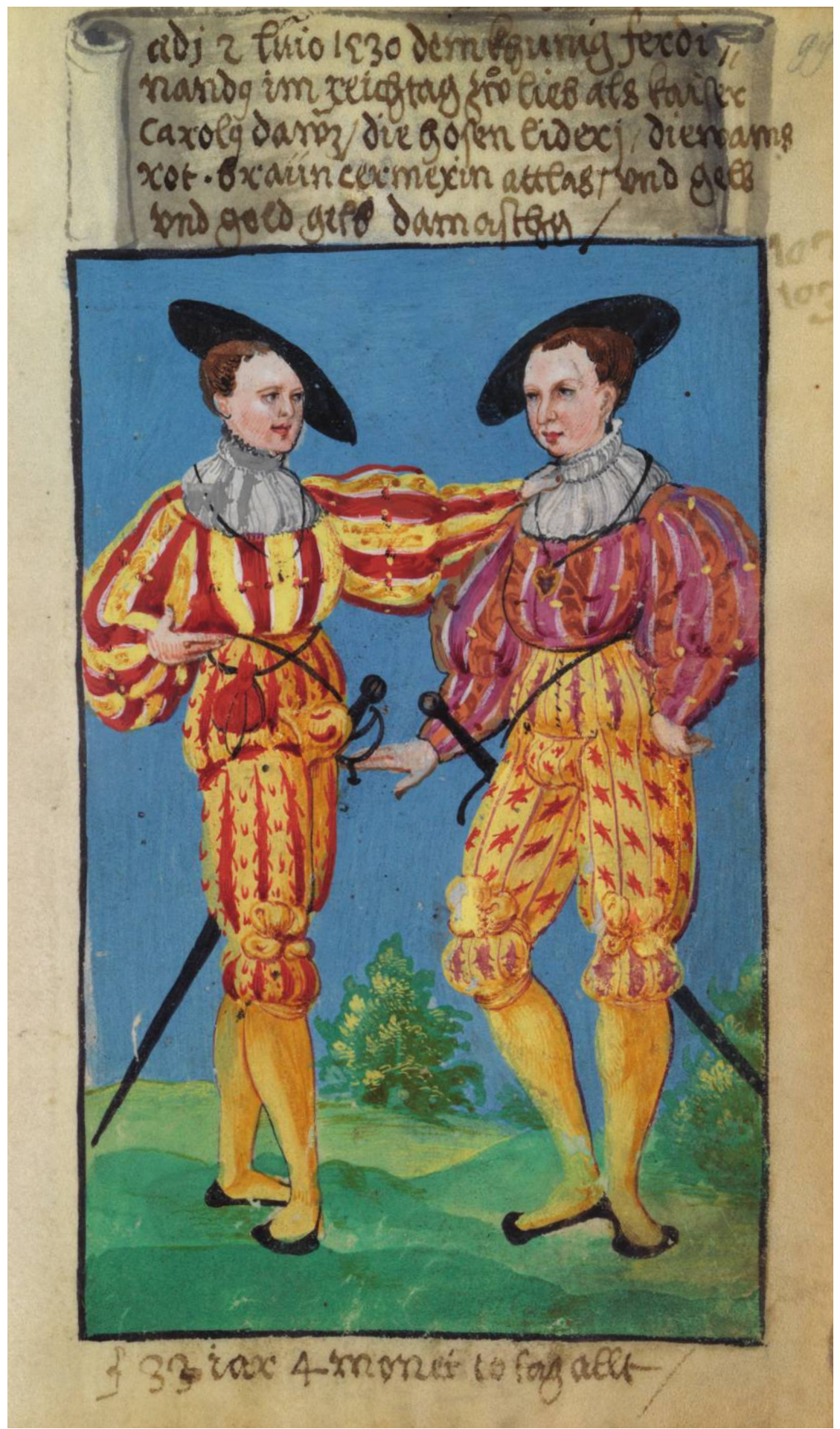


high Spanish nobility did appear in their customary black or golden velvet gowns, which exuded sumptuous elegance of a traditional, restrained kind; otherwise, at this point black was worn for mourning at courts. ${ }^{63}$ White was impractical, and green was too much linked to the notion of hope to be ideal for marking a strong stance at this summit. Red was an appropriate color, emphasizing vigor and a celebratory festiveness, which had also made it popular for elite weddings ${ }^{64}$ The Catholic Bavarians had frequently adopted a strong red for court dress and had done so continuously since 1527; it was thus expected that they would wear it again at the Imperial Diet in $1530 .{ }^{65}$ The Fugger family and their group of 132 servants on horseback adopted a moderate ash color for their entry, while the Augsburg merchants and civic servants (Stadtdiener) were dressed in liver color but prominently displayed different colors on their sleeves.

The key Protestant princes went with light red, an informed choice which signaled spiritedness but avoided signaling unity with Catholics. Yellow was considered the most splendid color apart from deep red, and Charles himself wore a "golden" riding coat and his bodyguards yellow coats which carried his Plus Ultra (further beyond) device. ${ }^{66}$ Ferdinand's retainers likewise wore yellow velvet gowns, while the Bavarian court—contrary to expectation—had been handed out dress in yellow and light red. ${ }^{67}$

\section{VI}

Schwarz had long cultivated a special connection with Ferdinand. He and five of his brothers had been part of the Augsburg delegation that greeted the Habsburg entourage outside the city in May 1521, after the Diet of Worms, which had placed Luther under the imperial ban. The two men were only six years apart in age-in 1521 Ferdinand was eighteen and Schwarz twenty-four. Schwarz was splendidly attired in long red and white ostrich feathers, the heraldic colors of the house of Austria. Jacob Fugger the Rich hosted Ferdinand and agreed the Habsburgs' first substantial loans. Schwarz would have been part of negotiations, and indeed by June he moved on to Austrian Linz to be part of the wedding festivities in honor of Ferdinand and Anna of Hungary-Queen Mary of Hungary's sister-in-law. Hungary was an area crucial to the Fuggers' mining interests. ${ }^{68}$

In Linz, Schwarz wore bright yellow hose for the first time, which might well have been prescribed as appropriate dress for the wider party. Later, in 1524, he had a simple bright-yellow hose with a trunk hose made, and then an elaborate bright-yellow hose for a business trip to the Tyrolian mining town of Hall. A spectacular archery outfit followed when he resumed the sport at age thirty-one, in 1528. In this case he proudly described the color of the outfit as "golden" and the effect of the silk-satin doublet as resembling "gold thrown with dice in the sun" (gold in der sunnen gewirfelt) because of its deep-saturated color and luminous splendor. The June 1530 garments for the Imperial Diet of Augsburg would be the last bright-yellow outfit Schwarz would ever commission, at a time when his help in financing Ferdinand's power through his position as head accountant of the Fugger firm was most needed. 

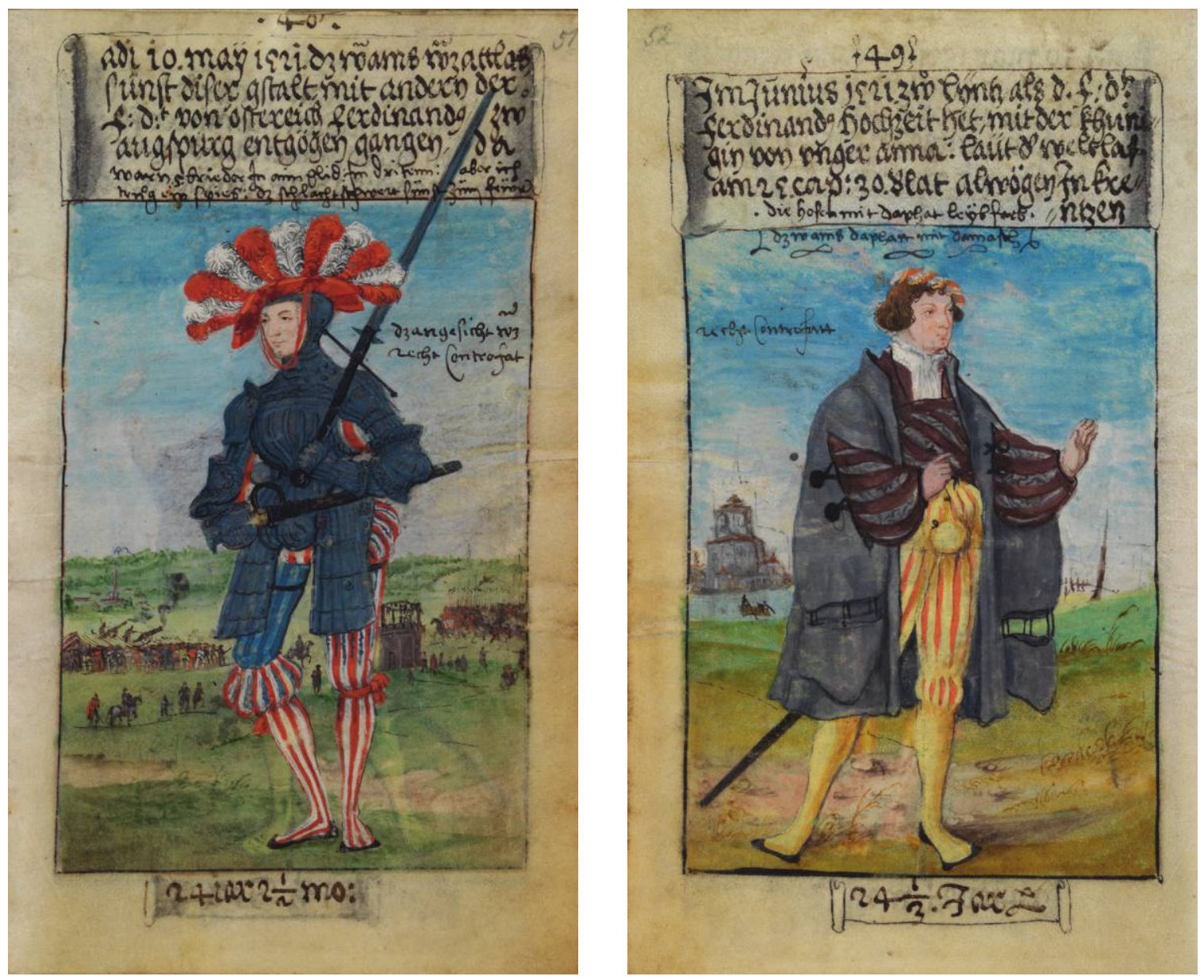

Fig. 5 (left) Matthäus Schwarz with Narziss Renner (illuminist), "Little Book of Clothes. Image 48, 1521. Herzog Anton Ulrich Museum, Brunswick, Germany.

Fig. 6 (right) Matthäus Schwarz with Narziss Renner (illuminist), "Little Book of Clothes." Image

49, 1521. Herzog Anton Ulrich Museum, Brunswick, Germany.
Anton Fugger, a nephew of Jacob, in the summer of 1530 was ready to enter into a contract over Upper Hungarian salines with Ferdinand's enemy Johan Zapolya. Zapolya's rule as king of Hungary was disputed by Ferdinand, who also claimed the title. Zapolya told Anton Fugger in July that negotiations would be possible once the Fuggers ended their financial support for Ferdinand and thus undermined Ferdinand's position in Hungary. Even though Fugger decided against pursuing the contract further, he knew that the door remained open and that his contacts with Zapolya strengthened his position with the Habsburgs in relation to other rival merchants firms, above all the Welsers, and in relation to Fugger's demands that previous credits should be repaid. ${ }^{69}$

Yet by September 1530 — and presumably not least through their head accountant's advice-the Fuggers' support for Ferdinand had been secured. A whole package, ranging from funds for the election as king to personal loans and support against the Turks, was agreed, which alongside older debts surpassed one million Rhenish florins. ${ }^{70}$ Charles V's largest-ever contract of mortgaged debts with the Fuggers followed on the 15th of October 1530. As a result, Anton 

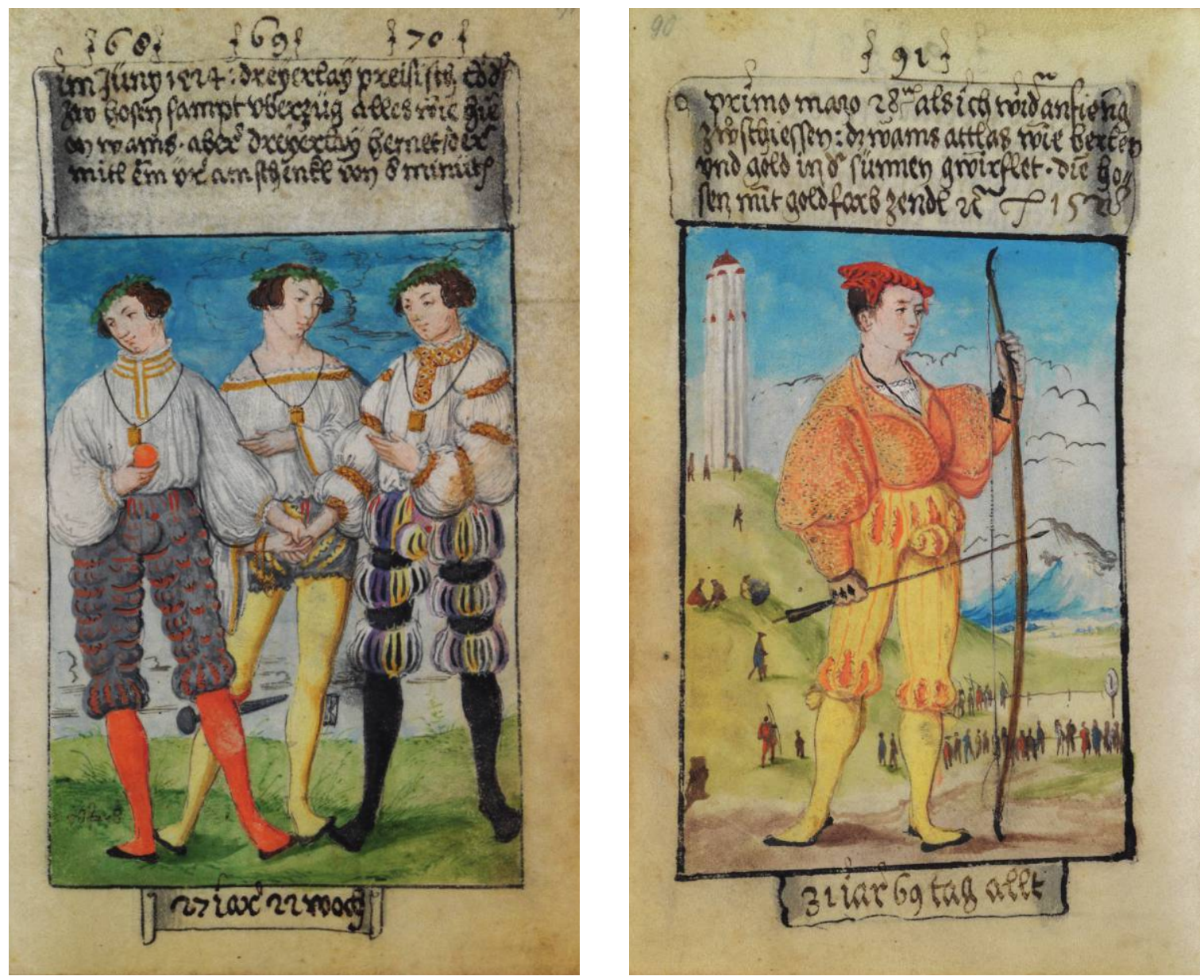

Fugger strengthened his own role as territorial lord and fantasized about his possible future as a duke, following the model of the newly empowered Medici in Florence. ${ }^{71}$ At the same time, the Fuggers attempted to secure their presence in South America and the Pacific immediately after Ferdinand's election in 1531. The Council of India agreed that the Fuggers should launch three voyages, each with five hundred armored men on three to four caravels. In return, three generations of the Fuggers would gain key economic, administrative, and military positions in conquered territories. This was an age in which a new merchant class conducted global politics through the power of trade. ${ }^{72}$

\section{VII}

Our only evidence for Schwarz's outfit at the Imperial Diet of Augsburg is a small watercolor image with its own imperfections (see fig. 4). The inscription records that the hose were made of leather, the doublet of "red-brown-scarlet" silk satin and "yellow and gold yellow damask." This means that different surface
Fig. 7 (left)

Matthäus Schwarz with Narziss Renner (illuminist), "Little Book of Clothes." Image 69-70, 1524. Herzog Anton Ulrich Museum, Brunswick, Germany.

Fig. 8 (right)

Matthäus Schwarz with Narziss Renner (illuminist), "Little Book of Clothes." Image 91, 1528. Herzog Anton Ulrich Museum, Brunswick, Germany. 
textures came together, through the leather, satin, and Italian patterned damask, and needed to work together in color harmony but also generate visual interest by reflecting light in different ways. Schwarz also wore a high-necked linen shirt with wide sleeves. As accessories he had on silk garters, a purse, a sword, two belts worn across each other, a necklace, and a flat bonnet. In addition, he sported the short haircut the Habsburgs had just begun to favor. Because no outer gown could be worn in the heat of summer, the whole outfit and Schwarz's body were on view all the time. In order to perfectly achieve this delicate, wellshaped look, Schwarz had also recently slimmed down-this emphasized his youth, fine judgment, and moderation and enabled elegant movement to radiate the honor and splendor expected in court.

In 2012, I commissioned an interpretation of this garment from the acclaimed director of the London School of Historical Dress, Jenny Tiramani, and a team of experts on Renaissance leather garments and caps. This collaborative process immediately made clear that to create such an outfit was a notable achievement in aesthetic production. For a customer like Schwarz it involved coordinating a team of craft experts in different workshops for a period of months. It would draw on conversations with makers as well as knowledge about color recipes recorded in Kunstbüchlein, which were published especially in the mining towns as well as in centers of book printing like Augsburg. Schwarz regularly visited the Fugger mining towns and corresponded with factors, some of whom were friends and most of whom shared his fascination with dress. It was common for male friendship groups at the time to attend weddings similarly dressed. Thus the act of making became a subject of conversation, as it involved identifying a color and a fabric for everyone to wear-unless the material was supplied-as well as a shape and the construction. It is easy to imagine that such exchanges in the Fugger circle thrived on discussion about the possibilities of accessing particular quantities of global dyestuffs to produce especially brilliant colors. In fact, Matthäus Schwarz considered the bright-red fabric given to those attending Anton Fugger's wedding as a sensational high point of happiness in his life. It contrasted vividly with the black he also wore on that occasion, and the whole is captured in the image of him which concludes his "Little Book of Clothes," at age sixty-three. ${ }^{73}$

This once more alludes to the fact that he and his contemporaries could regard colors as related to intrinsic qualities and powers. Strong reds were seen as carriers of life and heat, while a strong yellow was linked to gold as metal, which had been given its power by the influence of the sun. Its warmth vivified, signaled persistence, and united heaven and earth in the noblest way. It was refined and incorruptible. Mining treatises spelled out such cosmologies and hierarchies, placing lead with its unrefined mercury content at the bottom. ${ }^{74}$ Such ideas were integral to an "underlying framework for artisanal practices," which recognized the influence of the heavens over humans and the earth and also saw the "workings of the human body and its humors" as a model for all natural processes. Art was viewed as the "human practice of making visible the hidden powers in nature." Minerals and humans were tempered by the movements of heaven, and humors in turn could be tempered with specific diets, such as eating butter to counteract metal vapors or warming food to ward off 
cold miasma. ${ }^{75} \mathrm{~A}$ focus on color suggests that it was similarly seen to temper humors, such as melancholy, or to protect oneself from them or to constitute specific emotional qualities, such as defiance, loyalty, and cheerfulness, which radiated out to others. ${ }^{76}$

This further explains why matter and its manipulation fascinated contemporaries to such an extent, and why they inquired into the behavior of natural materials, ranging from bark, flowers, berries, and mordants to the type of water to be used (such as "fresh water from a well" or "flowing water"), and their interrelation with particular fabrics or leather. As Pamela Smith argues, we therefore might think of a final object as the residue of an enormous number of cultural exchanges among individuals and of their belief systems, organized practices, networks, and accumulated knowledge. Objects inscribe the memory of previous generations' innovations and cognitions, and their making requires very significant expertise. This expertise is itself the result of a "culture" that has multiple layers-of socialization within a craft, a network of workshops, patterns of consumption and production. Techniques of making tell us about knowing. ${ }^{77}$

Such knowledge began with the sourcing of materials. In order to have a long, intact piece to work with, leather needed to be procured from tanners with access to high-quality deerskin without ticks, which left holes. After having the hair scraped off, the hide was treated with different chemical substances to make it white and extremely smooth. ${ }^{78}$ It would then be dyed.

For the reconstruction, this presented us with the first challenge: how to replicate the golden-yellow color that was so important not only to the look but also to its emotional and social effect at the time. The yellow was felt to be an energizing stimulant of emotion, and this vibrant effect was further heightened through its combination with red in the lining, which was pulled out. In the reconstruction process, the dyeing of leather with natural substances went wrong the first time, which is no doubt why Schwarz and his craftsmen would have tested and experimented with the dyes first. The color was just not quite vibrant enough. In Schwarz's time, such faded hues of yellow could have negative associations of weakness and coldness, which is why they were used to stigmatize Jews. Persian berries finally achieved a golden yellow through several applications, while curcuma (tumeric) as well as particular types of onion and gorse (Ginster) would have been other contemporary alternatives ${ }^{79}$ Based on research into Eastern recipes, Rosetti's Plictho advised:

To make skins yellow

You will take skins that are dressed by the leaf. For each skin take one and a quarter ounces of curcuma that is pestled and two ounces of roche alum. Set to cook in two half mezzette of clear water and make it boil so much that it drops by one third. After having done this, spread out your skins and give them of this color, one hand. Set it to cool and then to dry. When it is dried, give it one more hand and do this until it gets the color you like. Having done this, give it the soap, the pole, the button of glass, and you will have a fine color. 

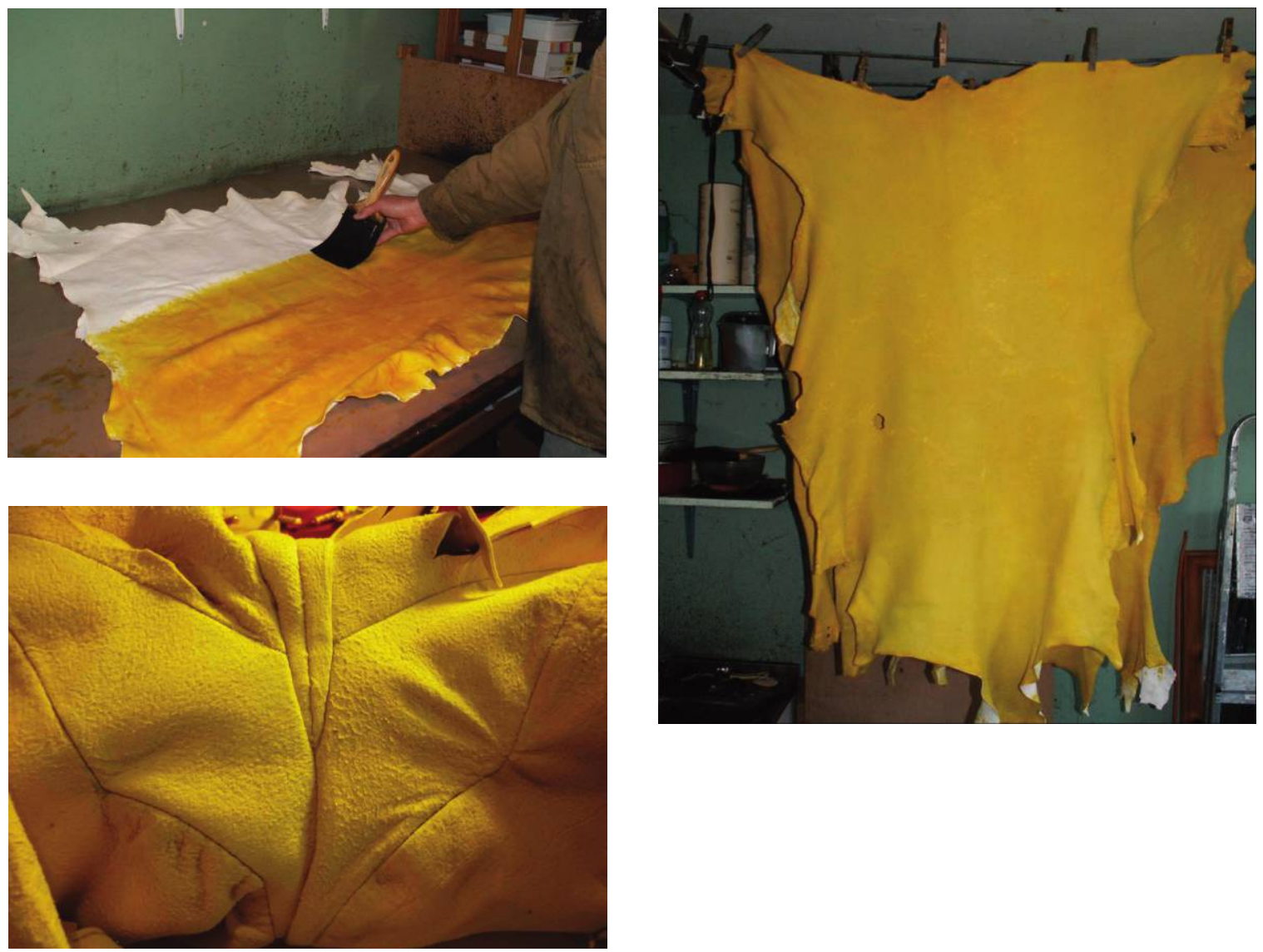

Fig. 9 (top left)

Dyeing the alumed deerskin. Photo: Karl

Robinson.

Fig. 10 (right) Drying the deerskin. Photo: Karl Robinson.

Fig. 11 (bottom left) Geometrical cut and construction techniques

for the hose. Photo: Jenny Tiramani.
To dye a skin that will seem of gold

Measure litharge of gold two ounces, oil of walnuts three ounces, and incorporate them well and see that the litharge is well pulverized. Make it boil so much that it drops a third, and with those two parts smear the skins on the side where the hair is, and set in the sun to dry. If the oil were too little add some more, as when incorporating you will see, and more while you are doing the work. ${ }^{80}$

The difficulty of this process and Rossetti's instruction to adjust amounts until you get a "color you like" underline that successful dyes invited visual interest and admiration and required know-how and a commitment to aesthetic perfection in such a display. Other sixteenth-century color recipes called for berries picked at a specific time of the year ("the later the better") to achieve richness, clarity, and beauty and specified how crucial it was to patiently repeat the dyeing process. Recipes can still be replicated today. ${ }^{81}$

All this suggests that it would have been known at the time how to dye the leather of the hose in exactly the same tone of yellow as the doublet panes. Yet the reconstruction also revealed that the leg garment was not as laborious to make as might be assumed. The slits in the leather were made swiftly and 

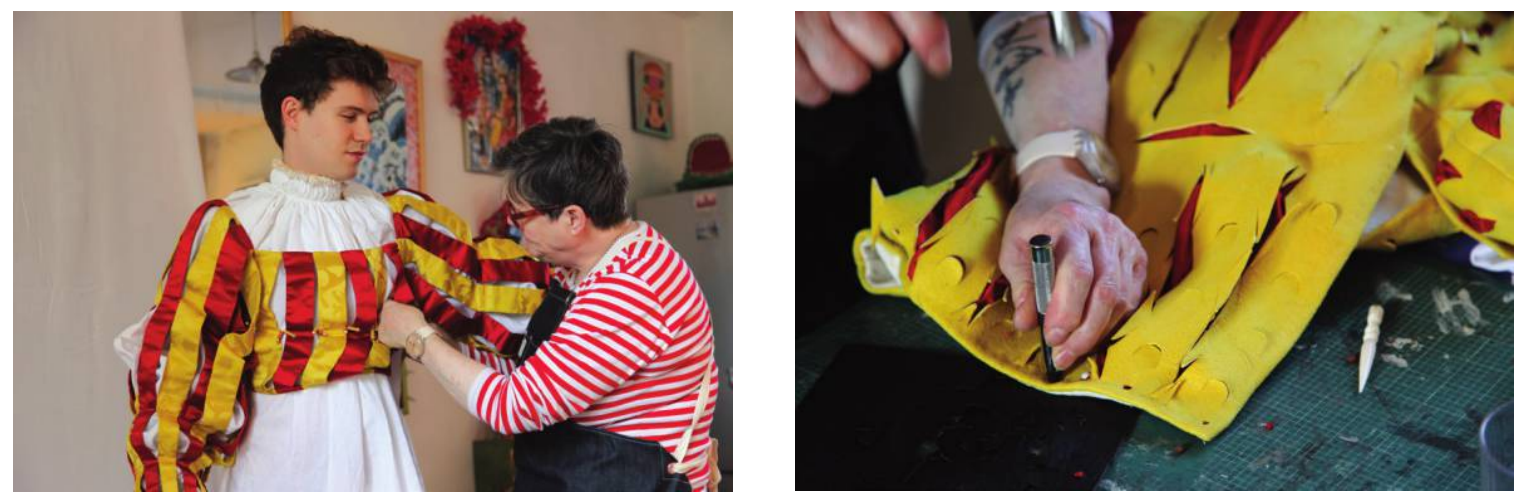

required no hemming, as leather does not fray or tear if pinking tools are correctly applied. Schwarz's garment can be compared to an extant contemporary German princely outfit in yellow, which belonged to Duke Moritz of Saxony. This would have been far more demanding and time-consuming to make, as it consisted of an overhose with different panes made in velvet, bound in silk strips and lines. ${ }^{82}$

Schwarz chose to pair his relatively cheap leg garment with a complicated doublet. This upper-body garment imitated royal dress in its construction, as can be demonstrated by comparison with the well-known 1535 portrait of Francis I by Jean Clouet that hangs in the Louvre. The reconstruction revealed that Schwarz's doublet would have consisted of 48 separate panes in yellow and red. Each pane had four layers, so that the tailor and seamstresses had to handle a total of 192 pieces of fabric. These panes had to be sewn into an extended bulbous shape at the front. In the reconstruction this proved challenging because of the metal aglets which intricately connected the panes. The metal pulled the panes down so that it was impossible to arrange the shirt in the way Renaissance people found desirable. Contemporary craftspeople surely learned from such experiences and turned their knowledge to good use when working for different clients. Embroidery with metal threads, for example, added firmness and weight to fabric, but it would have been worn mainly by princes. It hardly ever featured in Schwarz's fashions because it meant highly labor-intensive work, an aristocratic, sumptuous luxury.

Like the doublet, the wide-brimmed plate bonnet wound up requiring further stiffening, with cotton, linen, or animal hair, to perfectly stay in shape. It was tightly knit with fine merino-wool yarn on very thin needles to achieve a high stitch count and density of fabric. Then it was dyed and fulled through repeated immersion in hot, soapy water and repeated beating with a mallet as well as kneading and rolling. ${ }^{83}$

Crafting such items of clothing in the sixteenth century particularly strengthened investigative rather than codified knowledge, through developing techniques to achieve new effects. At certain points, accumulated experience nonetheless needed to consolidate into firmer judgment and cognition-for instance,
Fig. 12 (left)

Fitting the luminous damask and silk-satin doublet, London, 2012. Photo: Ulinka Rublack.

Fig. 13 (right) Hammering holes into the hose, London, 2012. Photo: Ulinka Rublack. 

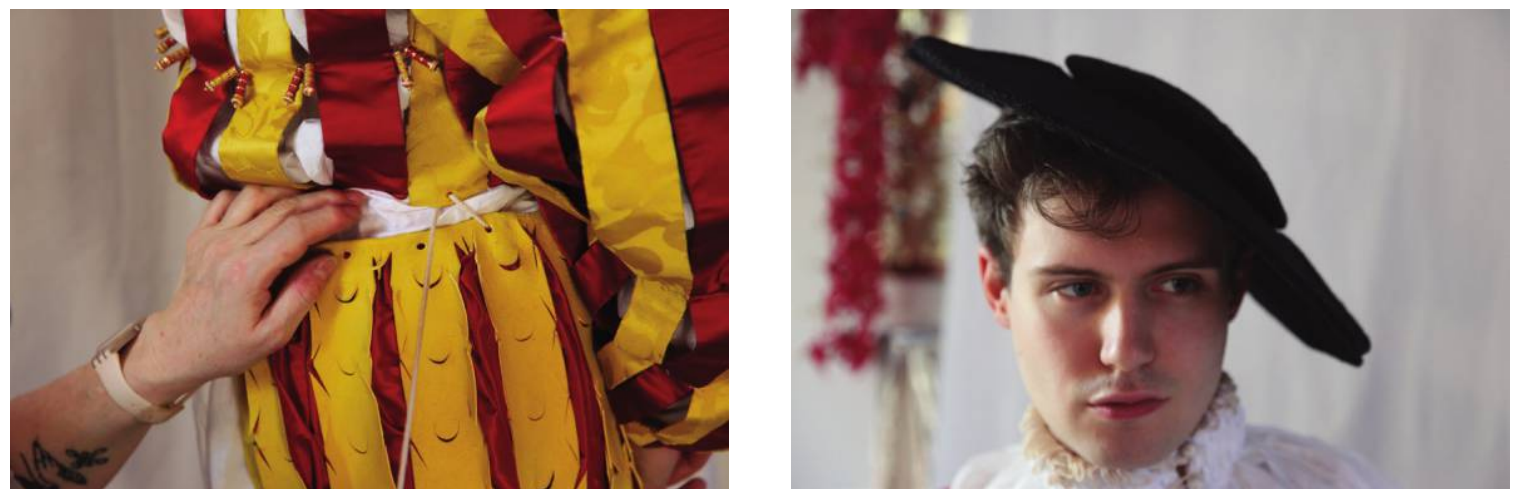

Fig. 14 (left) Lacing the doublet and hose at the fitting, London, 2012. Photo:

Ulinka Rublack.

Fig. 15 (right) Jack Brotchie with the felted beret, London, 2012. Photo: Ulinka Rublack. in the process of hammering, with complete precision and "split second determination," the holes into the leather hose to connect the leg garment with the upper garment. ${ }^{84}$ No remaking of the holes was possible, and these were exciting moments when expertise was tested and craftsmanship needed to be guided by confident cognition.

Reconstruction trains visual acuity, as one is able to better register the intelligence of the hand that has crafted a garment or other object. This in turn makes one understand the deep investment of people in the past in driving technological ingenuity forward to perfection. Part of the excitement was that experiments emotionally involved customers in their failure or success, in improvisation and trained intuition, in regard to materials which were already in themselves pleasurable to look at and touch. Materials offered sensual rewards, through their softness or snugness, and as they held a person in a posture that was both upright and graceful. Such dress was made to measure, with methods for alterations in mind if it was meant to last. This craftsmanship with foresight made it durable and clever. Through many fittings, still customary in made-to-measure tailoring today, fashionable items of dress transmitted confidence to a clientwho would know that he would please and impress a discerning audience. At the same time such dress also imposed its own temporality and insecurities, because it required the wearer to maintain a precise weight and pristine look.

In sum, the impression made by Schwarz's outfit constituted an emotional effect of enlivened gaiety—Fröhlichkeit—and steadfastness, because the outfit was made in precisely the colors that Ferdinand seems to have favored most for celebratory occasions at court. Such an outfit therefore was about a profound practice of visual accomplishment that drew attention to how it was made. Yet it did so by fitting in and not using too many costly materials. Schwarz signaled restraint from being overly sumptuous by avoiding velvet; a doublet with long, wide sleeves; any gold, silver, or silk embroidery; or pearls to decorate the collar, which even peasants needed to be asked to refrain from in the imperial sumptuary legislation agreed by the 1530 Augsburg Diet. ${ }^{85}$ Above all, this remarkable accountant showed that he knew his place, as he proclaimed his loyalty to the Catholic Habsburgs through dress and lobbied for favors which would ultimately grant his ennoblement. 


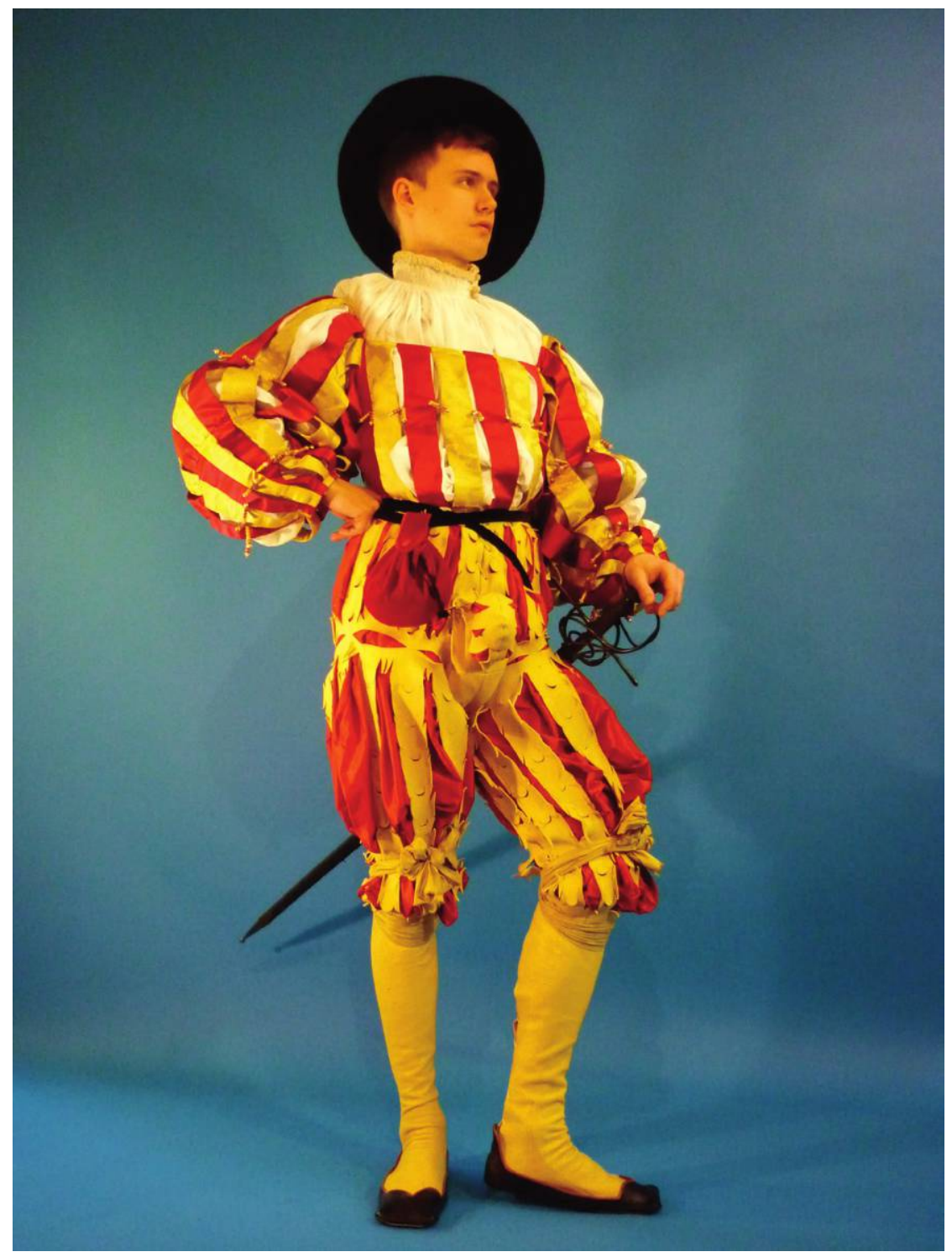

Fig. 16

Jenny Tiramani, an interpretation of

Matthäus Schwarz's 1530 outfit, London, 2013. Photo: Jenny Tiramani.

\section{IX}

Through such sophisticated experiments and shapes, Schwarz's outfit exemplified the values of good craftsmanship and created a satisfying visual experience along the lines identified by Baxandall as "period eye." As Baxandall has shown, there existed almost no written aesthetic theory in Renaissance Germany, which in turn meant that style remained empirically grounded in culture and of necessity heterogeneous rather than rigorously systematic. ${ }^{86}$

Baxandall's analysis of the aesthetic vocabulary in contracts shows that around 1500 the key descriptors of the good craftsmanship and satisfying visual 
experience demanded by patrician patrons were "well-shaped, elegantly decorated in ornamentation, pleasantly contrived, fine, subtle in physical delicacy and refinement, skilful." In contrast, the word grob, "rough," was associated with peasant crudity. ${ }^{87}$ An Augsburg Ars Memorativa in 1490 illustrated the notion of subtlety with an image of patient needlework for commercial purposes, so that patrons of this process by implication endorsed the craft skills needed for embroidery as part of a wider view of the world and social hierarchies. Baxandall's work on calligraphy in turn has shown that this society's "visual interest" expressed itself in relation to patterns into the 1530s through a differentiated vocabulary including terms like "folded, plaited, circle-like, chain-like, inverted" which describe "connection and disconnectedness (geteilt, geschied, kettenweis) or underlying form (spiegelweiss, verkert, versetzt), or the total effect (verwirrt)." Added to this, in writing as much as in music, would then be the bravura flourish to distinguish a composition as a whole; in sculpture this would usually be achieved through flourishes of drapery. The feeling of these patterns was captured by the following adjectives: free, graceful, delicate, sweet, mild, simple, strong, gay, fresh, and severe (frey, fein, überzart, süss, sanft, bloss, stark, frölich, frisch, streng). Particular combinations of these preferences for patterning then served to express a particular creative mood in the artwork to establish character or feeling. ${ }^{88}$

It is easy to apply the relevance of such terms of pattern, form, and feeling to dress. Dress was often constructed through different panes on doublets and hose, which might be slashed, wound, and embroidered with particular motifs, while sleeves on gowns were constructed and connected in a wide variety of ways, and linen shirts were skillfully pleated. Following Baxandall, we can therefore learn the particular uses of these shapes alongside color to communicate emotions or feelings, such as gaiety and freshness. Colors gained new resonance as languages of loyalty or dissimulation in relation to the religious troubles which divided Augsburg citizens as well as in relation to the Habsburgs' quest to augment the power of their dynasty.

\section{$\mathbf{X}$}

This was a society intimately involved with how things were made and what they were made from. There was tremendous innovation in techniques, materials, and aesthetic appreciation. Historians thus need not only to look at finished things but to follow the stories of matter and making to understand the achievement and effect of a broad range of artifacts which changed visual dispositions and supported or promoted emotional lives in the material Renaissance. Researching, handling, and remaking a specific object enables us to engage with it on a sensory level and to understand it as a potentially novel and striking visual act as well as in relation to particular agents and concrete usages. Otherwise we may be left to understand or consider artifacts only by type and as collective cultural representations. To one leading writer on the history of dress, German male dress appears extreme, bizarre, opulent, exaggerated, and capacious, a "strange beauty." Yet our primary work as historians remains to find Renaissance sources which tell us about the meaning given to dress in that 
society and how materiality shaped it. For, as the anthropologist Daniel Miller writes, "[t]he continual process by which meaning is given to things is the same process by which meaning is given to lives. ${ }^{" 89}$ Dress was a key aesthetic concern in the Renaissance, and ever since then it has remained a fundamental driver of commerce, cultural expression, and exchange across the world. ${ }^{90}$

What I have tried to show is how dress was used symbolically to affect political strategies, particularly to claim a relationship to those in power. I have further demonstrated how during a key political event, the Imperial Diet of Augsburg in 1530, three aesthetic languages articulated themselves: the language of costly treasure for the elites, the language of Protestant critique, and the language of a loyal Catholic bourgeois like Matthäus Schwarz, which spoke in the continued idiom of Renaissance civility through an endorsement of commerce, craft, and connoisseurship at the highest level of a measured splendor.

Knowledge about the precise make and historical context of dress across society can help us decode the meanings of dress as ingenious visual acts and the aesthetic as well as emotional arguments in a particular milieu. It can be informed by collaboration with experts to reconstruct historical dress, which integrates an understanding of making and performance into scholarly practices and suggests new historical questions. My historical contextualization of the politics and deeper emotional meanings of color in this period was initially prompted by Tiramani's question at the beginning of the reconstruction process: "So what yellow did Schwarz wear?" As the garment was made and I attended an extended fitting, the vibrant yellows achieved by natural dyes and their mimesis of gold spurred me to focus my research on color and its uses in symbolic communication, which has so far received insufficient attention by historians of this period.

This approach suggests an epistemology which argues that we can enrich our understanding of the effects of objects from a past world by experiencing their sensory, tactile qualities and unique properties. As the anthropologist Tim Ingold, historian Pamela H. Smith, and philosopher Jane Bennett eloquently argue, it resists the idea that we can understand the meanings of an object exclusively in terms of its social construction. Such an approach widens our understanding of what it means to be a historian of the visual by engaging with the materiality of what becomes a thing. Research therefore in part becomes a creative exchange among different practitioners. ${ }^{91}$ This research process can entail getting in touch with matter in an involved way-by registering the suppleness of a skin tawed with alum, or the effects of a dye in relation to lightreflecting fabrics such as satin and damask-as constitutive of experience and in collaborative processes which involve sensory perception rather than exclusively analytical activity trained in the mind. It prompts us to ask challenging questions: What does it mean to know something? What does it mean to know a portrait, its functions and meaning? Should we consider what a viewer in its own period might have focused on? How is knowledge established by particular disciplines? How can we enrich knowledge-gathering processes while maintaining rigorous historical contextualization through archival evidence? I suggest that in looking at portraits, for instance, we move away from trying to establish what someone is wearing merely to identify it. We need to ask instead how an item of dress 
would have been made-as animal, vegetable, and mineral matter transformed by human ingenuity into an aesthetic object-in a process akin to polychrome sculpting. It is crucial to explore what this aesthetic experience might have entailed, and whether the person depicted was trying to draw attention to particular accomplishments, displayed through an object's make in a specific historical setting and in response to particular social, religious, and political contexts. ${ }^{92}$ This moves us closer to understanding the period significance of dressing as a ubiquitous and often surprisingly complex visual act, performed in daily life. These visual acts were interrelated with material iconologies, in which individual pigments—-such as red and yellow—or materials—such as gold or velvet-could carry meanings which were activated by particular actors in specific settings..$^{93}$ For historians of the visual, in other words, dress in its shapes, qualities, and colors must become central to fully comprehend the period eye.

\section{Ulinka Rublack}

Ulinka Rublack is professor of early modern European history at the University of Cambridge and a fellow of St. John's College. Among her publications are Dressing Up: Cultural Identity in Renaissance Europe (Oxford University Press, 2010), which won the Bainton Prize and was shortlisted for the 2011 Cundhill Prize, and The Astronomer and the Witch: Johannes Kepler's Fight for His Mother (Oxford University Press, 2015). Rublack is currently working on a monograph titled "A Made World," which investigates cultures in relation to materialities such as leather, feathers, and color during the early modern period.

Epigraph University Library Cambridge, Baxandall Papers, Typescript No. 2002, with an intended foreword for a new edition of Baxandall's The Limewood Sculptors of Renaissance Germany, p. 4. I wish to thank members of the "Materialized Identities Project," and in particular Susanna Burghartz, Lucas Burkhardt, Christine Göttler, and Stefan Hanss, for discussing a previous draft of this article with me, as well as Jenny Tiramani for many conversations.

1 I am grateful to Melanie Braun for discussing this subject with me at a workshop to re-create historical patterns, as well as to Hilary Davidson, who likewise reconstructs historical dress. Juan de Alcega, The Tailor's Pattern Book, 1589, ed. J. L. Nevinson, facsimile edition (New York: Costume and Fashion Press, 1999); Katherine Barich and Marion McNealy, Drei Schnittbücher: Three Austrian Master Tailor Books of the 16th Century (n.p.: Nadel and Faden Press, 2015) - this is an edition of surviving manuscripts which focuses on gowns. For concepts of embodied cognition in relation to aesthetics, see John Michael Krois, Bildkörper und Körperschema (Berlin: Akademie Verlag, 2011).

2 Michael W. Cole, Cellini and the Principles of Sculpture (Cambridge: Cambridge University Press, 2002), 53.

3 Paul Hills, Venetian Colour: Marble, Mosaic, Painting and Glass, 1250-1550 (New Haven, CT: Yale University Press, 1999), 185.

4 Michael Baxandall, The Limewood Sculptors of Renaissance Germany (New Haven, CT: Yale University Press, 1980), 42.

5 Many aspects of what I would term body sculpting through dress in the period are wonderfully illustrated in Denis Bruna, ed., Fashioning the Body: An Intimate History of the Silhouette (New Haven, CT: Yale University Press, 2015, published for the Bard Graduate Center).

6 Elegy XIX. This was memorably performed by Jenny Tiramani in the National Portrait Gallery on 25 October 2013.

7 For a general exploration, see Herman Roodenburg, The Eloquence of the Body: Perspectives on Gesture in the Dutch Republic (Zwolle: Waanders, 2004).

8 Ulinka Rublack, “Matter in the Material Renaissance," Past and Present 219, no. 1 (2013): 41-85.

9 Theodor Hampe, Nürnberger ratsverlässe über Kunst und Künstler im Zeitalter der Spätgotik und Renaissance (Vienna: Karl Graeser, 1904), 1:24.9.1520.

10 Jeffrey Chipps Smith, Dürer (London: Phaidon, 2012), 345.

11 Hans Rupprich, ed., Dürer, Schriftlicher Nachlass 3 (Berlin: Deutscher Verein für Kunstwissenschaft, 1969), 3:167. 
12 See Herbert L. Kessler's crucial book Seeing Medieval Art (Toronto: University of Toronto Press, 2011), 175.

13 Carolin Oster, Die Farben höfischer Körper: Farbattributierung und höfische Identität in mittelhochdeutschen Artus- und Tristanromanen (Berlin: De Gruyter, 2012), 66.

14 Timothy McCall, "Brilliant Bodies: Material Culture and the Adornment of Men in North Italy's Quattrocento Courts," I Tatti Studies in the Italian Renaissance 16, no. 1 (Fall 2013), 445-90.

15 Carina Johnson, Cultural Hierarchy in Sixteenth-Century Europe: The Ottomans and Aztecs (New York: Cambridge University Press, 2011), 111: "Si quid unquam honoris humana ingenia in huiuscemodi artibus sunt adepta, principatum iure merito ista consequentur. Aurum, gemmasque non admiror quidem, qua industria, quove studio superet opus materiam, stupeo."

16 The Correspondence of Erasmus, 1523 to 1524, trans. R. A. B. Mynors and A. Dalzell, annotated by J. M. Estes (Toronto: University of Toronto Press, 1992), 129, my emphasis. The Middle Ages had already evaluated small objects in devotional contexts, but they had not been of small value. A particularly interesting study of the material iconography of precious small objects is Simone Husemann, Pretiosen persönlicher Andacht: Bild- und Materialsprache spätmittelalterlicher Reliquienkapseln (Agnus Dei) unter besonderer Berücksichtigung des Materials Perlmutter (Weimar: VDG, 1999).

17 Michel Pastoureau, Black: The History of a Color (Princeton, NJ: Princeton University Press, 2009). 18 "Ist also die alte welt wider ney worn." Georg Steinhausen, ed., Briefwechsel Balthasar Paumgartners des jüngeren mit seiner Gattin Magdalena, geb. Behaim (1582-1598) (Stuttgart: Schriften des literarischen Vereins, 1895), 150.

19 Aspects of this process are explored in Alexander Engel, Farben der Globalisierung: Die Entstehung moderner Märkte der Farbstoffe 1500-1900 (Frankfurt-am-Main: Campus, 1990); Judith H. Hofenk de Graaff et al., eds., The Colourful Past: The Origins, Chemistry and Identification of Natural Dyestuffs (London: Archetype, 2004); Jo Kirby et al., eds., Natural Colorants for Dyeing and Lake Pigments: Practical Recipes and Their Historical Sources (London: Archetype, 2014); Emil Ernst Ploss, Ein Buch von alten Farben: Technologie der Textilfarben im Mittelalter (Heidelberg: Heinz Moos, 1962).

20 On the long-term development of knowledge about dyeing, see Agustí Nieto-Galan, "Between Craft Routines and Academic Rules: Natural Dyestuffs and the 'Art' of Dyeing in the Eighteenth Century," in Materials and Expertise in Early Modern Europe: Between Market and Laboratory, ed. Ursula Klein and E. C. Spary (Chicago: University of Chicago Press, 2010), 321-53, here p. 345.

21 The wider trajectory of such perceptions is explored in Karin Leonhard, Bildfelder: Stilleben und Naturstücke des 17. Jahrhunderts (Oldenbourg: Akademieverlag, 2013); see also Twarin Baker, Sven Dupré, Sachiko Kusukawa, and Karin Leonhard, eds., Early Modern Color Worlds, Early Science and Medicine 20 (Leiden: Brill, 2016).

22 The Plictho of Gioanventura Rosetti, ed. S. M. Edstein and H. C. Borghetty, 1548 edition (Cambridge, MA: MIT Press, 1969).

23 Ibid., 89.

24 Ibid., 90.

25 Allerley Mackel und flecken auß Gewand . . . zu bringen (Meintz: Jordan, 1532).

26 Plictho, 91.

27 Ibid., 109. Amy Butler Greenfield's A Perfect Red: Empire, Espionage, and the Quest for the Color of Desire (New York: HarperCollins, 2005) focuses on cochineal.

28 The Correspondence of Hans Fugger, 1566-1594, ed. Christl Karnehm (Munich: Bayerische Historische Kommission, 2003), 1:22.3.1569, to Hans Jörg von Preysing in Landshut as his intermediary. 29 Ulinka Rublack and Maria Hayward, eds., The First Book of Fashion: The Books of Clothes of Matthäus and Veit Konrad Schwarz of Augsburg (London: Bloomsbury, 2015), 352, 1557.

30 Spike Bucklow, The Alchemy of Paint: Art, Science and Secrets in the Middle Ages (London: Marion Boyars, 2009), 22-23.

31 Rublack and Hayward, First Book of Fashion.

32 Jo Kirby, Susan Nash, and Joanna Cannon, eds., Trade in Artists' Materials: Markets and Commerce in Europe to 1700 (London: Archetype, 2010), 249.

33 Ekkehard Westermann and Markus A. Denzel, eds., Das Kaufmannsnotizbuch des Matthäus Schwarz aus Augsburg von 1548 (Stuttgart: Steiner Verlag, 2011), 50-51; for Schwarz's own notes, see 302-4.

34 Ursula Haller, "'Administrator of Painting': The Purchase and Distribution Book of Wolf Pronner (1586-1590) as a Source for the History of Painting Materials," in Kirby, Nash, and Cannon, Trade, 325-35.

35 On this, see Lyndal Roper, "Tokens of Affection: The Meanings of Love in Sixteenth-Century Germany," in Dürer and His Culture, ed. Dagmar Eichberger and Charles Zika (Cambridge: Cambridge University Press, 1998), 155.

36 Rublack and Hayward, First Book of Fashion, 280.

37 Michel Pastoureau, Green: The History of a Color (Princeton, NJ: Princeton University Press, 2014), esp. 75-77.

38 Barbara Stollberg-Rilinger, Des Kaisers alten Kleider: Verfassungsgeschichte und Symbolsprache des Alten Reichs (Munich: Beck, 2008), 20, now translated by T. Dunlap as The Emperor's Old Clothes: Constitutional History and the Symbolic Language of the Holy Roman Empire (Oxford: Berghahn, 2015). 
39 Karl Brandi, Kaiser Karl V. Werden und Schicksal einer Persönlichkeit und eines Weltreichs (Munich: Bruckmann, 1967), 2:260; Stollberg-Rilinger, Des Kaisers, 93, 95.

40 Rosemarie Aulinger, Das Bild des Reichstages im 16. Jahrhundert (Göttingen: Vandenhoeck und Ruprecht 1980), 189, 175.

41 Harriet Rudolph, Das Reich als Ereignis: Formen und Funktionen der Herrschaftsinszenierung bei Kaisereinzügen (1558-1618) (Cologne: Böhlau, 2011), 75n171.

42 Die Chroniken der deutschen Städte vom 14. bis ins 16. Jahrhundert, vol. 23, Die Chronik von Clemens Sender von den ältesten Zeiten der Stadt bis zum Jahr 1536, ed. Friedrich Roth (Leipzig: Hirzel, 1894), 253.

43 For this quotation and the following one, see Stollberg-Rilinger, Des Kaisers, 101-36.

44 Deutsche Reichstagsakten unter Kaiser Karl V, vol. 8.1, ed. Wolfgang Steglich (Göttingen: Vandenhoeck und Ruprecht, 1970), 599.

45 Friedrich Roth, Augsburger Reformationsgeschichte, 4 vols. (Munich: T. Ackermann, 1911), 3:330.

46 Deutsche Reichstagsakten, 592, 599.

47 Martin Luther, Vermahnung an die geistlichen versamlet auff dem Reichstag zu Augsburg, Anno 1530 (Wittenberg: H. Lufft, 1530), 2: "doch nichts nutze da sein kundte / als an dem / inn solcher pracht und gescheffte nichts gelegen sein würde."

48 Stollberg-Rilinger, Des Kaisers, 15.

49 Die Chronik von Clemens Sender, 262.

50 Roth, Augsburger, 3:337.

51 Ibid., 3:339, 343, 345, 346, 348 .

52 Aulinger, Das Bild des Reichstages, 299: "auff das allerkostlichst, dergleichen nie gesehen ist worden. man hat diese krone geschetzt mit samt den anderen kaiserlichen klaidern me dan trei mal hundert tausendt gulden werdt zu sein."

53 Westermann and Denzel, Kaufmannsnotizbuch, 81-83, 376-77. This included transferring an annual pension of 12,000 ducats to the widowed sister of Charles and Ferdinand, Mary of Hungary. On the relationship between Fugger and Ferdinand, see also Mark Häberlein, Die Fugger: Geschichte einer Augsburger Familie (1367-1650) (Stuttgart: Kohlhammer, 2006), 82-87.

54 Aulinger, Das Bild des Reichstages, 344n9.

55 Heinrich Lutz, Conrad Peutinger: Beiträge zu einer politischen Biographie (Augsburg: Brigg, 1967), 315.

56 Roth, Augsburger, 350.

57 Stollberg-Rilinger, Des Kaisers, 11.

58 Ibid., 15.

59 Stephan Selzer, Blau: Ökonomie einer Farbe im spätmittelalterlichen Reich (Stuttgart: Hiersemann, 2010), 152-53.

60 Ibid., 124.

61 Ibid., 215.

62 Ibid., 153-54, 165; and for a table listing the court colors of Saxony, Hesse, and Bavaria between 1477 and 1551, 158-61.

63 Ibid., 169.

64 Ibid., 167-68.

65 Bayerische Staatsbibliothek Munich, Hofkleiderbuch, Cgm 1951, Nr. 182.

66 The complete description is in Aulinger, Das Bild des Reichstag, 337.

67 Selzer, Blau, 162.

68 Hans Kellenbenz, Die Fugger in Spanien und Portugal bis 1560, 2 vols. (Munich: Vögel, 1990), 1:66. 69 Götz, Freiherr von Pölnitz, Anton Fugger, 3 vols. (Tübingen: Mohr, 1958-86), 1:197-99; for background, see Géza Pálffy, The Kingdom of Hungary and the Habsburg Monarchy in the Sixteenth Century (New York: Columbia University Press, 2009), 37-41.

70 Pöllnitz, Fugger, 206-7.

71 Ibid., 207-9.

72 These plans were not realized owing to a lack of resources. Ibid., 225-27.

73 Rublack and Hayward, First Book of Fashion, 182.

74 Pamela H. Smith, "Making as Knowing: Craft as Natural Philosophy," in Ways of Making and Knowing: The Material Culture of Empirical Knowledge, ed. Pamela H. Smith, Amy R. W. Meyers, and Harold Cook (Ann Arbor: University of Michigan Press, 2014), 22-25.

75 Smith, "Making as Knowing," 25-27.

76 Bucklow, Alchemy of Paint.

77 Smith, "Making as Knowing," 20.

78 The best introduction to historical leather products and techniques is John W. Waterer, Leather Craftsmanship (London: G. Bell and Sons, 1968). In our case such high-quality leather could only be sourced from Montana.

79 Susanne B. Hohmann, ed., Das Prunkkleid des Kurfürsten Moritz von Sachsen (1521-1553) in der Dresdner Rüstkammer: Dokumentation—Restaurierung_Konservierung (Bern: Abegg Stiftung, 2008), $50-52$.

80 Plictho, 175.

81 Renate Woudhuysen-Keller, Das Farbbüchlein Codex 431 aus dem Kloster Engelberg, 2 vols. (Bern: 
Abegg-Stiftung, 2012), vol. 1, which footnotes several experiments to replicate recipes.

82 Hohmann, Das Prunkkleid; for the following analysis, see Jenny Tiramani's discussion of the reconstruction in Rublack and Hayward, First Book of Fashion, "Reconstructing a Schwarz Outfit," $374-96$.

83 The experienced capper Rachel Frost reports: "The chance to knit such a particularly large cap with such fine yarn on thin needles was an unusual opportunity to recreate the cap to the appropriate high level of craftsmanship not usually practical within most projects. This high stitch count and density of fabric produced a far closer representation of the type of cap we were aiming to portray and was notably different from the more usual chunkier reconstructions. Even with the tight knitting and heavy fulling, I concluded that a cap with such a large brim would require further stiffening, which itself raised new questions which will require further study." E-mail communication. 84 See Pamela H. Smith, "What Is a Secret? Secrets and Craft Knowledge in Early Modern Europe," in Secrets and Knowledge in Medicine and Science, 1500-1800, ed. Elaine Leong and Alisha Rankin (Farnham, UK: Ashgate, 2011), 65.

85 Matthias Weber, ed., Die Reichspolizeiordnungen von 1530, 1548 und 1577 (Frankfurt-am-Main: Klostermann, 2002), 141-42. Otherwise its chief intent was to limit expense on velvet and silks, especially red, shiny silk satin of the kind Schwarz used only in panes for his doublet.

86 Allan Langdale, "Art History and Intellectual History: Michael Baxandall's Work between 1963 and 1985" (PhD dissertation, University of California, Santa Barbara, 1995); Adrian Rifkin, ed., About Michael Baxandall (Oxford: Blackwell, 1999), esp. Malcolm Baker, "Limewood, Chiromancy and Narratives of Making: Writing about the Materials and Processes of Sculpture," 36-68, on the centrality of his alertness to materiality in sculpture.

87 Baxandall, Limewood Sculptors, 145.

88 Ibid., 152.

89 Daniel Miller, "Consumption," in Handbook of Material Culture, ed. Christopher Tilley (London: Sage, 2013), 417, and: "Material forms remain as one of the key media through which people conduct their constant struggles over identity and confront the contradictions and ambiguities that face them in their daily lives."

90 This is Aileen Ribeiro: "German styles were famed for their bizarre quality; the dominant aesthetics for men was dissonance in dress"; and further comments on p. 662, in "Dress in the Early Modern Period, c. 1500-1780," in The Cambridge History of Western Textiles, ed. David Jenkins (Cambridge: Cambridge University Press, 2003).

91 Llewellyn Negrin, "Fashion as Embodied Art Form," in Carnal Knowledge: Towards a New Materialism through Arts, ed. Estelle Barrett and Barbara Bolt (London: Tauris, 2013), 141-54; Sarah Pink, Doing Sensory Ethnography (London: Sage, 2009).

92 Cultures of discernment are explored in Christine Göttler and Sven Dupré's forthcoming book Hidden Artifices, and I am grateful to Christine Göttler for sending me the introduction.

93 This concept of affordances is central to Ann-Sophie Lehmann's publications; see, for instance, Lehmann, ed., "The Matter of the Medium: Some Tools for an Art Theoretical Interpretation of Materials," in The Matter of Art: Materials, Technologies, Meaning 1200-1700, ed. C. Anderson, A. Dunlop, and P. H. Smith (Manchester, UK: Manchester University Press, 2015). 